\title{
Kamu Çalışanlarının Stres Düzeylerinin Ölçülmesi ve Eskişehir Kamu Çalışanları Üzerine Bir Araştırma
}

\author{
Hüseyin GÜRBÜZ, Rüveyda DOĞAN, Elif GÖRMÜş, Gamze Pelin TOKYAY, Dilara ÖZTEKiN, Gökhan ENGiz*
}

Kamu Çalışanlarının Stres Düzeylerinin Ölçülmesi ve Eskişehir Kamu Çalışanları Üzerine Bir Araştırma

Özet

Stres kişinin etkinliğini ve verimliliğini olumsuz yönde etkileyen bir kavram olarak ortaya çıkmaktadır. Stresin yalnızca olumsuz ve başarıyı azaltan etkisinin yanında, olumlu yönleri olduğunu gösteren çalışmalar da vardır. Üretim verimliliğini artıran ve çalışanların sağlığını etkilemeyen stres olumlu olarak kabul edilmektedir ve iş hayatında stres daha çok çalışanların verimliliği üzerine yoğunlaşmaktadır. Bu çalışmada, araştırmanın teorik altyapısını oluşturan stres ve örgütsel stres kavramları üzerinde durulmuştur. Stresin insanda görülen belirtileri verilmiş, stresin örgütler üzerindeki etkileri incelenmiştir. Çalışma boyunca, Eskişehir'deki kamu çalışanları üzerine uygulanan bir araştırma ile çalışanların stres kaynakları ve çalışanlarda görülen stres belirtileri incelenmiştir. Çalışanlara uygulanan ankette yer alan önermeler, literatür taramasıyla elde edilen durumların tespiti ile oluşturulmuştur. Araştırma sonucunda, rahatsı edici düzeyde olmasa bile, kamu çalışanlarının değişik stres kaynaklarına maruz kaldıkları görülmüştür.
Stress Level Measurement of Public Employees A Research on Public Officials in Eskisehir

\section{Abstract}

Stress emerges as a concept which negatively affects the efficiency and the productivity of an individual. In addition to the negative and productivity lessening effects of stress, some researchers cited various positive effects of it. A stress level that affects an increase in productivity and that doesn't cause a deterioration of health is accepted as a positive one and the studies about stress in work life mostly focus on the productivity of the employees. This study was focused on the facts that stress forming the theoretical substructure and organizational stress concepts. The symptoms of stress upon humans as well as observed the effects of stress upon organizations were given. Through the study, the stress causing sources and the symptoms of stress was being observed by the research carried out upon the public employees in Eskisehir. The questions in the survey were formed by the search of specified cases in literature. We conclude that the public employees were exposed to various stress sources even in the case of stress sources were not an uncomfortable level.

Key Words: Stress, Public Employess

\section{Giriş}

Her sektörün verimli ve etkili olabilmesi için her çalışanın bireysel kapasitesini mümkün olan en üst düzeye çıkarmak, çalışma arzusunu arttırmak gerekliliği inkar edilemez bir gerçektir. İş görenler yaptıkları işten veya iş ortamından memnun oldukları, bulundukları ortamdaki stres faktörlerinden etkileşimlerinin minimum olduğu ölçüde bireysel motivasyonları sağlanır ve dolayısıyla aynı

* Hüseyin GÜRBÜZ, Yrd.Doç.Dr., Eskişehir Osmangazi Üniversitesi i.i.i.B.F. Sayısal Yöntemler Anabilim Dalı, hgurbuz2002@gmail.com; ESOGÜ Sosyal Bilimler Enstitüsü Yüksek Lisans Öğrencileri; Rüveyda DOĞAN, rdogan@ogu.edu.tr, Elif GÖRMÜŞ, elifip2005@hotmail.com, Gamze Pelin TOKYAY, gpelinty@hotmail.com, Dilara ÖZTEKiN, d_oztekin@hotmail.com , Gökhan ENGiZ, gengiz83@gmail.com 
Hüseyin GÜRBÜZ | Rüveyda DOĞAN | Elif GÖRMÜş | Gamze Pelin TOKYAY | Dilara ÖZTEKIN | Gökhan ENGiz

ölçüde çalışmalarında verimli olurlar. Günümüzde kamu kurum ve kuruluşları için sektöründe özel sektörde olduğu gibi insan sermayesinden en üst düzeyde yararlandığı ve böyle bir mekanizmayı başarılı bir şekilde çalıştırdığını söylemek zordur. Ancak işten çıkarılma korkusu, günlük işlerini yetiştirme sıkıntısı gibi iş stresinin bir parçası olan etkenler özel sektöre kıyasla kamu sektöründe az olduğu söylenebilir.

Bu çalışmanın amacl; stresi, belirtilerini, strese neden olan kişisel ve örgütsel faktörleri açıklamak ve stresle nasıl baş edileceği konusunda bilgi vermektir. Uygulama aşamasında ise kamu sektöründe çalışanların performansını etkileyen stresin çalışan memnuniyeti üzerine etkisi, uygulanan anket aracılıyla incelenecektir. Stres ve memnuniyet düzeylerinin çalışanların cinsiyet, medeni durum, yaş, eğitim seviyesi, tecrübe, aylık gelir, bölüm, statü ve şube gibi demografik özelliklerine göre dağılımı araştıılacaktır. Çalışanların performansı ve verimliliği çalıştıkları ortamdan memnuniyetleriyle alakalı olduğu daha önceki birçok araştırmada kanıtlanmıştır.

\section{Stres}

Stres kavramı, sanayileşen her toplumdaki bireylerin öğrenip kullandığı psikolojik kavramlardan biridir. Stres, herkes tarafından bilinmesine rağmen, çoğu insan bu kavramı hem yanlış hem de farklı anlamda kullanmaktadır. Stres denilince, çoğu insanın aklına hemen olumsuz ifade tarzı gelmektedir. Fakat böyle bir düşünce yanlıştır. Çünkü stres çalışma yaşamındaki şartlara göre zararlı veya zararsız olabilir. Başka bir deyişle, stresi iyi ve kötü biçimlerde düşünmek mümkündür. Örneğin, çok dersten ikmale kalan veya çok sevilen bir insanın hastalanmasından kaynaklanan stres kötü, çalışkan bir öğrencinin takdir listesine girmesi, insanların daha yukarılara terfi etmesinden kaynaklanan stres ise, iyi olarak değerlendirilir (Güney, 2007, s. 594).

Iwanchevich ve Matteson stres terimini; "uyaranlar, tepkiler ve iki etkinlik arasındaki etkileşim" biçiminde tanımlamışlardır. Lazarus'a göre stres "insanlar üzerinde fizyolojik, sosyal ve psikolojik sistemlerde rahatsızlık yaratabilecek aşırı taleplerin sonucudur" (Garipoğlu, 2007, s. 3).

\section{1. Çalışma Yaşamı ve Stres}

Bugünün modern toplumunda özellikle son derece gelişmiş ve aynı ölçüde karmaşıklaşmış olan örgütlerde yer alan insanları stressiz düşünmek mümkün değildir. İnsanlar yaşamlarının büyük bir kısmını işte geçiriyor. Dolayısıyla iş ortamında bulunan herkes zamanının çoğunu iş ve işle ilgili faaliyetlerini düşünerek geçirir. Fakat özellikle yönetim kademesinde yer alanların işi düşünmedikleri bir anını bulmak oldukça zordur. Bu nedenle insanı strese sokan temel faktörlerin başında iş yaşamının yer aldığını söylemek yanlış olmayacaktır (Güney, 2007, s. 595).

\subsection{1. Çalışma Yaşamında Stres Kaynakları}

Çalışma yaşamında stres yaratan (kişisel ve örgütsel stres faktörleri) faktörler karşısında bilim adamları birçok araştırma yapmış ve elde ettikleri verileri değerlendirerek bazı sınıflamalar yapmıştır. Sınıflandırma yapııırken dikkate alınan temel noktalardan bazıları şunlardır: 
- İşle Doğrudan ilgili Unsurlar,

- Çalışma Yaşamındaki Mesleki Gelişme,

- Çalş̧anların Örgütteki Rolü,

- Örgüt Dışı Sosyal lilişki,

- Örgütsel iklim.

Çalışma yaşamında stres yaratan faktörler bireyin çevresinde, stres ise bireyin kendisindedir. Stres yaratııılarını fiziksel, sosyal ve duygusal olmak üzere üç grupta toplamak mümkündür. Fiziksel stres kaynaklarl; çalışanın çevresinden kaynaklanan ve fiziksel bir strese yol açan ve insanı, sonuçlar konusunda endişeye yönelten kaynaklardır. Sosyal stres kaynakları çalışma yaşamındaki bireyler arası ilişkilerle ilgilidir. Burada stres yaratan fiziksel bir unsur değil başka bir insandır. Duygusal etmenler, çalışanların çevreleriyle olan ilişkilerini algılama biçimleri olup, kişide engelleme, kaygı, kızgınlık veya buna benzer stres duygularına neden olurlar (Güney, 2007, s. 598).

\section{3. Örgütsel Stres Kaynakları}

Şimşek ve Çelik'e göre mesleki farkıııklar, rol çatışması ve belirsizliği ile aşırı iş yükü ve az çalışma, fiziksel koşullar gibi faktörler, stresi oluşturan örgütsel faktörler olarak kabul edilmektedir.

McGrath’a göre stres faktörlerinin sınıflandırması şu şekildedir:

- Görev kaynaklı stres (işin zorluğu, belirsizliği ve iş yükünün fazlalığı vb.),

- Role bağlı stres (çatışma, rol belirsizliği, iş yoğunluğu vb.),

- Davranış ortamından kaynaklanan stres (kalabalığın etkisi vb.), (Akt. Ertekin, 1993)

Luthans'a göre örgütteki stres kaynakları dört grupta toplanmaktadır:

- Örgütsel Politikalar

- Örgütün Yapısal Özellikleri

- Fiziksel Koşullar

- Örgütsel Süreçler (Akgündüz, 2006, s. 26).

\section{Uygulama}

\subsection{Araştırmanın Amacı}

Kamu kurum ve kuruluşlarında çalışan personel, iş hayatında birçok nedenle stresle karşı karşıya kalmaktadır. Stresin kaynağı ve etkileri ise faaliyet gösterilen sektöre ve kişilere göre farklılık göstermektedir. Ancak gerek yapılan işin niteliği gerekse çalışlan ortamdaki maddi olanak, yöneticilerle iletişim, terfi gibi faktörler kişilerin beklentilerine göre farklıık göstermekte ve bu durumda az ya da çok her sektörde stresin varlığını hissettirmektedir. Araştırmamızda, değişik sektörlerde 
Hüseyin GÜRBÜZ | Rüveyda DOĞAN | Elif GÖRMÜş | Gamze Pelin TOKYAY | Dilara ÖZTEKIN | Gökhan ENGiz

faaliyet gösteren kamu çalışanları üzerinde stresin etkileri incelenmiştir. Stresin çalışanlar üzerinde etkileri bireysel ve örgütsel olmak üzere iki boyutta ele alınarak stresin etkileri bu boyutlar altında gözlemlenmiştir. Araştırmamızın amacı kamu çalışanlarının iş hayatında karşılaşabilecekleri stres kaynaklarını, çalışanların stres düzeylerini azaltmaya yönelik bulguları, strese karşı koyma yollarını ortaya çıkararak bu faktörlerin yeniden düzenlenmesi, çalışanlardaki stresin azaltılarak gerek çalışanların yaşam kalitesinin artırılmasına gerekse sunduğu hizmetin iyileştirilmesine ışık tutmaktır.

\subsection{Araştırma Yöntemi}

Milli Eğitim, PTT Başmüdürlük, Üniversite (ESOGÜ), Gelir İdaresi kurumları başta olmak üzere bu kurumlarda çalışanlar araştırma evrenimizi oluşturmaktadır. Araştırmamızda mekan sınırlaması yapılarak Eskişehir ili ele alınmıştır. Araştırmamızın anket soruları Eskişehir ilinde bulunan her kamu kurumunda çalışan personele basit tesadüfi yöntemle seçilerek 100'er adet dağıtılmış, 271 kişi anketimizi doldurarak geri göndermiştir. Eskişehir ilinde faaliyet gösteren kamu kurum ve kuruluşlarında çalışan 271 kişi araştırmamızda örneklemi oluşturmaktadır.

Yapılan araştırmada veri toplama yöntemlerinden anket metodu kullanılmaktadır. Anket soruları literatürdeki Esra GARIPOĞLU tarafından 2007 yılında hazırlanan "Stres Yönetimi ve Banka Çalışanları Üzerine Yapılan Bir Araştırma" başlıklı tez araştırmasında uygulanan anket formundan yararlanılmıştır.

Anket çalışmasında; örgütsel stres kaynaklarını oluşturan 62 önerme ve personelin demografik özelliklerini belirleyici 8 soru yer almıştır. Ankette önermelere verilecek cevaplar için beş aralıklı Likert Ölçeği kullanılmıştır. Araştırmaya katılanlardan, kendilerine en uygun gelen seçeneği doldurmaları istenmiştir. Puanlama ise, önermelerin her biri strese neden olacak şekilde verilmiş olduğundan, işaretlenen basamağın taşıdığı ağılık alınmıştır. Örneğin; “Kesinlikle Katılıyorum” seçeneğini işaretlemiş olan anket katılımcısı o önerme için 5 puan, "Kesinlikle Katılmıyorum" seçeneğini işaretlemiş olan katılımcı, 1 puan almıştır.

Tablo 1. Stres Kaynaklarına illişkin Önermelerin Dağılımı

\begin{tabular}{lrr}
\hline \hline Önerme Sırası & Stres kaynakları & Adet \\
\hline $1-28$ & (A) Yapılan İşin Özelliği ile illgili Stres Kaynakları & 28 \\
$29-37$ & (B) Yönetici ile Illgili Stres Kaynakları & 9 \\
$38-44$ & (C) Mesleki İlerleme, Terfi, Takdir ile Illgili Stres Kaynakları & 7 \\
$45-51$ & (D) Maddi Olanaklar ile Illgili Stres Kaynakları & 7 \\
& TOPLAM & 51 \\
\hline
\end{tabular}


Puanlamada, 3 puan "Kararsızım" tercihine karşılık gelmektedir. Böylece anketteki önermelerin her birine verilen cevaplar stres puanı olmuştur. Her önerme için, stres puanlarının katılımcı sayısına oranı ile, tüm katılımcıların ortalama stres puanları hesaplanmıştır.

Stres kaynaklarını, kendi aralarında 6 temel gruba ayırarak, ortalama değerleri hesaplanmıştır. Yüksek puanlar, stres kaynaklarının denekler açısından önemli stres yapıcılar olduğunu göstermektedir.

Buna göre, kararsız kalan ve 3 puanı tercih eden anket katılımcılarının eğiliminin 2 veya 4 puana ne kadar ve hangisine yakın olabileceği belli değildir. Bu nedenle, stres ortalama puanı 3'ün üzerinde olan stres nedenleri personeli nasıl etkilediği yorumlanmıştır.

\subsection{Güvenilirlik Analizi}

Çalışma için hazırlanan anketin güvenilirliğini ölçmek için, bu çalışmada 271 denek üzerinde uygulama yapılmış olup, Cronbach Alpha değeri (güvenilirlik katsayısı) hesaplanmıştır. Geliştirilen Likert tipi anket verilerinin güvenilirliği ölçülmüş, analiz sonucunda, anket verilerinin Alpha katsayısı, 0,942 olarak saptanmıştır. Bu değer 1.00'a yakın bir değer olduğundan anketin güvenilir olduğuna ve dolayısıyla uygulamada kullanılmasına karar verilmiştir.

\section{Bulgular ve Yorumlar}

Ankete Katılanların Demografik Özellikleri: Bu ankete katılan kişilerin demografik özellikleri kapsamında cinsiyetlerine, medeni durumlarına, yaş gruplarına, eğitim düzeylerine, toplam çaış̧ma sürelerine, bulundukları sektördeki çalışma sürelerine, gelirlerine ve çalıştıkları sektöre göre dağılımlarında sahip oldukları özellikler şöyledir:

Tablo 2. Demografik Özelliklerin Yüzdelik Dağılımı

\begin{tabular}{llrr}
\hline \hline Demografik özellikler & & Adet & Yüzde (\%) \\
\hline Cinsiyet & Kadın & 137 & 50,6 \\
& Erkek & 134 & 49,4 \\
Medeni durum & Evli & 85 & 31,4 \\
& Bekar & 85 & 31,4 \\
Yaş aralığı & 25 'den az & 13 & 4,8 \\
& $25-30$ yaş & 57 & 21 \\
& $30-35$ yaş & 57 & 21 \\
& $35-45$ yaş & 83 & 30,6 \\
Eğitim durumu & 45 yaş ve üzeri & 61 & 22,5 \\
& Orta öğretim & 53 & 19,6
\end{tabular}


Hüseyin GÜRBÜZ | Rüveyda DOĞAN | Elif GÖRMÜŞ | Gamze Pelin TOKYAY | Dilara ÖZTEKiN | Gökhan ENGiZ

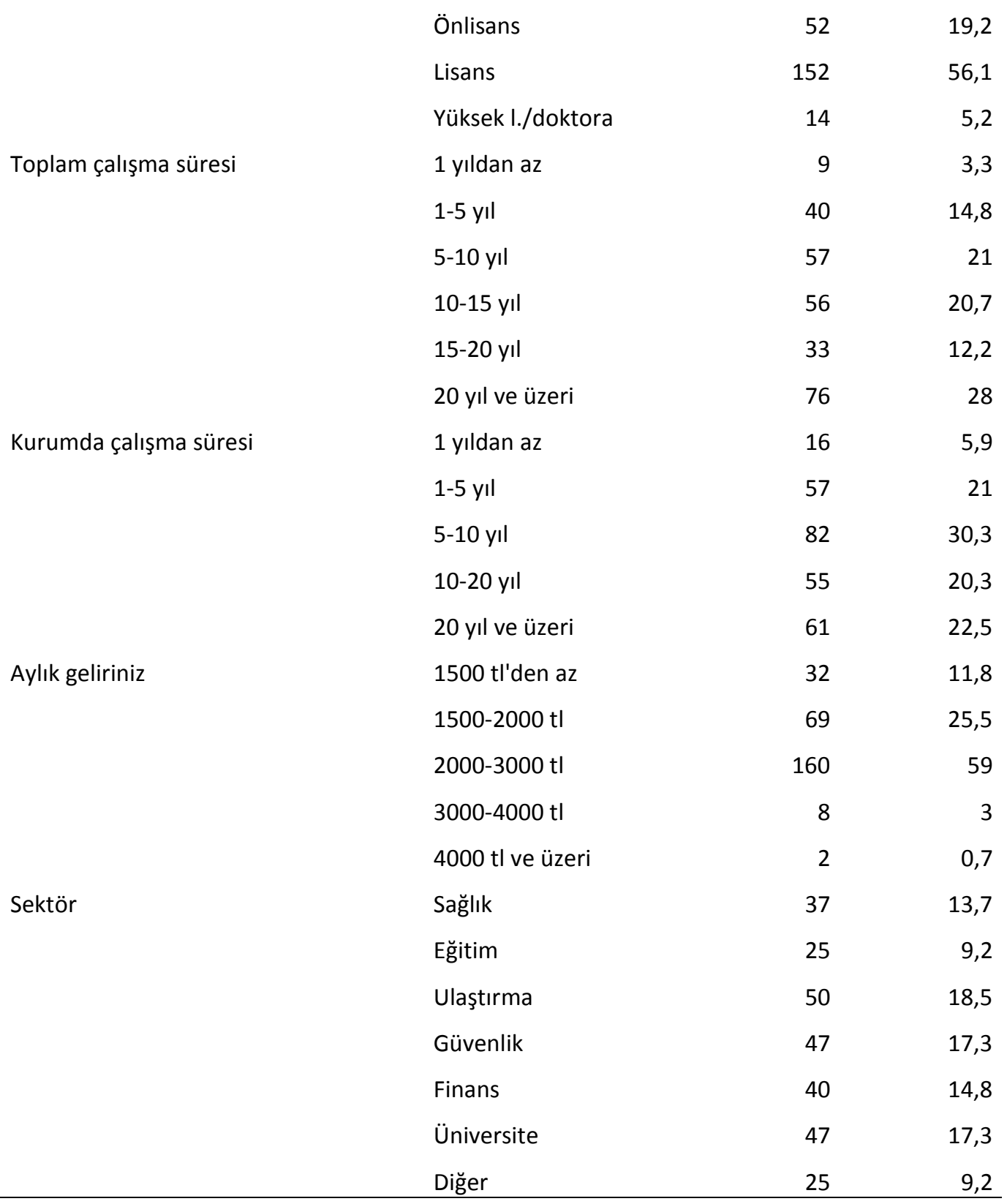




\subsection{Yapılan İşin Özelliği ille ilgili Stres Kaynaklarının Değerlendirilmesi}

Yapılan işin özelliği ile ilgili stres kaynaklarının neler olabileceği değerlendirildiğinde, toplam 28 ifadeden 23'ü 3 ve üzerinde değer almıştır. Yapılan işin özelliği ile ilgili stres kaynaklarına bakıldığında çalışma saatlerindeki düzensizlik, görev ve sorumluluk alanlarının tam olarak belirlenmesinden kaynaklanan çalışanlar tarafından yapılan işlerin anlamsız bulunuşu, yöneticilerin açık net ifadelerle ne istediğini belirtmemesi stres kaynağı olarak görülmektedir. Bunun yanı sıra iş yerindeki izin problemleri de strese yol açmaktadır. Çalışanların daha iyi iş yapma çabalarının engellenmesi konusu stres kaynağı gibi görülmekle birlikte, daha iyi iş yapma gayretinin kurumun çalışma talimatları ile çatışmaması ve yapılan araştırma ve inceleme sonucu elde edilen görüşlerin yöneticilerin tecrübe ve öngörüleri ile çelişmemesi konusu göz ardı edilmemelidir. İşlerin zamanında görülmesi ve ilgili işin bitirilmesi için ayrılan sürenin verimli ve etkin kullanılabilmesi çok önemlidir.

Tablo 3. Yapılan İşin Özelliği ile İlgili Stres Kaynakları

\begin{tabular}{|c|c|c|c|}
\hline Sira & Soru & Ort. & Öncelik \\
\hline 23 & Çalışma saatlerim düzenli değil, sık sık değişiyor & 3,99 & 1 \\
\hline 2 & Bazen işimi anlamsız buluyorum & 3,71 & 2 \\
\hline 28 & $\begin{array}{r}\text { Görev ile ilgili sorumluluklarım açık değil, benden ne istendiğini } \\
\text { bilmiyorum }\end{array}$ & 3,68 & 3 \\
\hline 4 & Bu mesleğin amaçları benim için yeteri kadar açık değil & 3,67 & 4 \\
\hline 15 & İş yerinde aşırı disiplin ve baskı yaşıyorum & 3,56 & 5 \\
\hline 7 & İşimin zevk alınabilir özelliği yoktur & 3,56 & 6 \\
\hline 22 & Çalışırken kullandığım araç-gereç ve teçhizat yeterli değil & 3,46 & 7 \\
\hline 27 & Kapasitemi aşan işleri yapmam bekleniyor & 3,42 & 8 \\
\hline 21 & Çalışma koşullarım oldukça ağır ve çalışma süreleri çok uzun & 3,40 & 9 \\
\hline 24 & Yaptığım işler değişik ve renkli değil, sıkıcıdır & 3,36 & 10 \\
\hline 14 & Günlük izin talebim problem yaratıyor & 3,35 & 11 \\
\hline 11 & İş yerinde kendimi aileden biri gibi hissetmiyorum & 3,34 & 12 \\
\hline 25 & Yıllık izinlerimi tam ve zamanında kullanamıyorum & 3,34 & 13 \\
\hline 9 & Yıllık izinlerim eşimin yıllık izinleri ile uyuşmuyor & 3,31 & 14 \\
\hline 8 & İşyeri ile ilgili sorunlarım var & 3,30 & 15 \\
\hline 10 & İşimle ilgili yayınları (kitap, dergi vb.) takip edemiyorum & 3,26 & 16 \\
\hline 16 & Görevimin her anında parasal risk alma korkusu yaşıyorum & 3,22 & 17 \\
\hline
\end{tabular}


Hüseyin GÜRBÜZ | Rüveyda DOĞAN | Elif GÖRMÜŞ | Gamze Pelin TOKYAY | Dilara ÖZTEKiN | Gökhan ENGiZ

\begin{tabular}{lrrr}
\hline \hline 12 & Iş̧ortamında özgür değilim ve kişiliğimden ödün veriyorum & 3,19 & 18 \\
20 & Çalışma ortamım yeteri derecede rahat değil & 3,19 & 19 \\
26 & İş yerinde yeterli internet imkanı sağlanmıyor & 3,17 & 20 \\
13 & Iş̧imle ilgili konularda benim görüşüm alınmıyor & 3,12 & 21 \\
3 & İyi iş yapma çabalarım, işe özel bürokrasi tarafından engellenmektedir & 3,07 & 22 \\
17 & İşimle ilgili yeni gelişmeler konusunda eğitim alamıyorum & 3,05 & 23 \\
1 & İşimdeki kural ve yöntemlerin bir çoğu işimi iyi yapmamı zorlaştırıyor & 2,91 & 24 \\
19 & İşlerin görülmesinde zaman sıkıntısı yaşıyorum & 2,89 & 25 \\
5 & İşyerinde yapmam gereken işlerin miktarı çok fazla & 2,81 & 26 \\
18 & Iş̧ yükünün çok fazla ve iş temposunun yorucu olduğunu düşünüyorum & 2,72 & 27 \\
6 & İşim çok fazla kırtasiye gerektiriyor & 2,70 & 28 \\
\hline
\end{tabular}

\subsection{Yönetici ile İlgili Stres Kaynaklarının Değerlendirilmesi}

Yönetici ile ilgili stres kaynakları değerlendirildiğinde, toplam 9 ifadeden 7 adedi 3 ve daha üzerinde değer almıştır. Tabloda ortaya çıkan duruma göre, yöneticilerin işini bilen, yetenekli, iletişim becerilerine sahip olmamaları çalışanlara arasında stres yaratmaktadır. Yöneticilerin iş akışının aksamaması için çalışanlarını eğitime yeterince göndermemesi, çalışanın bilgi eksikliği olduğunu düşündüğü konularda bir iş yaparken kendilerini stres altında hissedebilmektedir.

Tablo 4. Yönetici ile İlgili Stres Kaynakları

\begin{tabular}{lrrr}
\hline \hline Sıra & Soru & Ort. & Öncelik \\
\hline 29 & Yöneticim işinde yetenekli değildir & 3,70 & 1 \\
36 & Verilen görevin ne olduğu tam olarak açıklanmıyor & 3,69 & 2 \\
30 & Yöneticim bana karşı adil değil & 3,64 & 3 \\
35 & Astlarımla etkili iletişim kuramıyorum & 3,64 & 4 \\
34 & Yönetici ve üstlerimle etkili iletişim kuramıgorum & 3,47 & 5 \\
31 & Yöneticicilerim memurlarının duygularına çok az ilgi gösterir & 3,41 & 6 \\
33 & Birden çok kişiye aynı anda sorumlu oluyorum & 2,93 & 8 \\
32 & Benden sürekli başarılı olmam bekleniyor & 2,85 & 9 \\
37 & & 3,35 & 7 \\
\hline
\end{tabular}




\subsection{Mesleki İlerleme, Terfi ve Takdir ile ilgili Stres Kaynaklarının Değerlendirilmesi}

Mesleki ilerleme, terfi ve takdir ile ilgili stres kaynakları değerlendirildiğinde, toplam 7 stresörden 1'i 3 ve daha üzerinde değer almıştır. Kamu sektöründe terfi durumlarında siyaset, üst makamlarda tanıdık birilerinin olması avantaj sayılabilmesi çalışanları terfi durumlarında stres kaynağı olmaktadır.

Tablo 5. Mesleki İlerleme, Terfi ve Takdir ile İlgili Stres Kaynakları

\begin{tabular}{lrrr}
\hline \hline Sıra & Soru & Ort. & Öncelik \\
\hline 43 & Erken terfi eden arkadaşım benden daha başarısızdı & 3,01 & 1 \\
39 & Bana ödedikleri parayı düşündüğümde, kurum tarafından takdir & 2,96 & 2 \\
& edilmediğimi düşünüyorum & & \\
38 & İyi bir iş yaptığım zaman gereken takdiri göremiyorum & 2,93 & 3 \\
40 & İnsanlar bu iş̧e, başka işlerde olduğu kadar hızlı terfi edemezler & 2,78 & 4 \\
44 & Gösterdiğim çabalar karşılığında, hak ettiğim biçimde & 2,51 & 5 \\
42 & ödüllendirildiğimi sanmıgorum & 6 \\
41 & Burada çalışanlar için çok az ödül vardır & 2,31 & 7 \\
\hline
\end{tabular}

\subsection{Maddi Olanaklar ile İlgili Stres Kaynaklarının Değerlendirilmesi}

Maddi olanaklar ile ilgili stres kaynakları değerlendirildiğinde, toplam 7 stres kaynağından 1'i 3 ve üzerinde değer almaktadır.

Tablo 6. Maddi Olanaklar ile Illgili Stres Kaynakları

\begin{tabular}{|c|c|c|c|}
\hline Sira & Soru & Ort. & Öncelik \\
\hline 49 & $\begin{array}{r}\text { İstihkaklarımı zamanında alamıyorum, aldıklarımın ölçüleri } \\
\text { bana uymuyor }\end{array}$ & 3,20 & 1 \\
\hline 45 & İşimin sağladığı maddi imkanlardan memnun değilim & 2,79 & 2 \\
\hline 46 & $\begin{array}{r}\text { Elde ettiğim maddi imkanlar diğer mesleklerin sağladığı } \\
\text { kadar değildir }\end{array}$ & 2,75 & 3 \\
\hline 47 & $\begin{array}{l}\text { Yaptığım işin karşılığı olarak bana sağlanan kazanç ve diğer } \\
\text { imkanlar, harcadığım emeğe karşılık gelmemektedir }\end{array}$ & 2,75 & 4 \\
\hline 51 & Elde etmem gereken fakat elde edemediğim haklarım var & 2,49 & 5 \\
\hline 50 & Emeklilik ve gelecekle ilgili kaygılarım var & 2,34 & 6 \\
\hline 48 & Maaş artışlarından memnun değilim & 2,28 & 7 \\
\hline
\end{tabular}


Hüseyin GÜRBÜZ | Rüveyda DOĞAN | Elif GÖRMÜŞ | Gamze Pelin TOKYAY | Dilara ÖZTEKiN | Gökhan ENGiZ

\subsection{Yapılan İ̧̧in Özelliği ile ilgili Stres Kaynaklarının Sektörel Karşılaştırması}

Yapılan işin özelliği ile ilgili stres kaynaklarının sektörlere göre farklılı̆ını ölçmek için tek yönlü varyans analizi testi uygulanmıştır.

Tablo 7. Varyans Analizi Tablosu

\begin{tabular}{lrrrrr}
\hline \hline Değişkenlik Kaynağı & Kareler Toplamı & S.d & Kareler Ortalaması & $F$ & $P$ \\
\hline Gruplar Arası & 66,835 & 6 & 11,729 & 15,284 & 0,0001 \\
Gruplar İçi & 192,412 & 264 & 0,729 & & \\
Toplam & 259,247 & 270 & & & \\
\hline
\end{tabular}

$p<\alpha(0,0001<0,05)$ olduğundan dolayı sektörlere göre stres faktörü açısından anlamlı bir farklıık bulunmaktadır. Bu farklılığın hangi sektörden kaynaklandığını belirlemek için yapılan Tukey çoklu karşılaştırma sonuçları Tablo 8'de verilmiştir.

Tablo 8. Tukey Çoklu Karşılaştırma Tablosu

\begin{tabular}{llrrrrr}
\hline \hline \multirow{2}{*}{ Sektör } & Sektör & Ortalama & \multirow{2}{*}{ S.d. } & \multicolumn{2}{c}{ \% 95 Güven Aralığı } \\
\hline \multirow{2}{*}{ Sağlık } & Eğitim & $-0,51224$ & 0,22102 & 0,240 & $-1,1689$ & 0,1445 \\
& Ulaştırma & $-0,08569$ & 0,18513 & 0,999 & $-0,6358$ & 0,4644 \\
& Maliye & 0,33279 & 0,18763 & 0,567 & $-0,2247$ & 0,8903 \\
& Finans & $1,03913^{*}$ & 0,19473 & 0,000 & 0,4605 & 1,6177 \\
& Üniversite & $-0,51634$ & 0,18763 & 0,090 & $-1,0738$ & 0,0412 \\
& Diğer & 0,07451 & 0,22102 & 1,000 & $-0,5822$ & 0,7312 \\
& Sağlık & $-0,51224$ & 0,22102 & 0,240 & $-0,1445$ & 1,1689 \\
& Ulaştırma & 0,42655 & 0,20912 & 0,392 & $-0,1948$ & 1,0479 \\
& Maliye & $0,84503 *$ & 0,21133 & 0,002 & 0,2171 & 1,4729 \\
& Finans & $1,55136 *$ & 0,21766 & 0,000 & 0,9047 & 2,1981 \\
& Üniversite & $-0,00410$ & 0,21133 & 1,000 & $-0,6320$ & 0,6238 \\
& Diğer & 0,58675 & 0,24147 & 0,190 & $-0,1307$ & 1,3042 \\
& Sağlık & 0,08569 & 0,18513 & 0,999 & $-0,4644$ & 0,6358 \\
& Eğitim & $-0,42655$ & 0,20912 & 0,392 & $-1,0479$ & 0,1948 \\
\hline
\end{tabular}


Eskişehir Osmangazi Üniversitesi Sosyal Bilimler Dergisi

\begin{tabular}{|c|c|c|c|c|c|c|}
\hline & Maliye & 0,41848 & 0,17345 & 0,197 & $-0,0969$ & 0,9338 \\
\hline & Finans & $1,12482 *$ & 0,18110 & 0,000 & 0,5867 & 1,6629 \\
\hline & Üniversite & $-0,43065$ & 0,17345 & 0,170 & $-0,9460$ & 0,0847 \\
\hline & Diğer & 0,16020 & 0,20912 & 0,988 & $-0,4611$ & 0,7815 \\
\hline \multirow[t]{6}{*}{ Maliye } & Sağlık & $-0,33279$ & 0,18763 & 0,567 & $-0,8903$ & 0,2247 \\
\hline & Eğitim & $-0,84503 *$ & 0,21133 & 0,002 & $-1,4729$ & $-0,2171$ \\
\hline & Ulaştırma & $-0,41848$ & 0,17345 & 0,197 & $-0,9338$ & 0,0969 \\
\hline & Finans & $0,70633^{*}$ & 0,18365 & 0,003 & 0,1607 & 1,2520 \\
\hline & Üniversite & $-0,84913^{*}$ & 0,17611 & 0,000 & $-1,3724$ & $-0,3259$ \\
\hline & Diğer & $-0,25828$ & 0,21133 & 0,885 & $-0,8862$ & 0,3696 \\
\hline \multirow[t]{6}{*}{ Finans } & Sağlık & $-1,03913^{*}$ & 0,19473 & 0,000 & $-1,6177$ & $-0,4605$ \\
\hline & Eğitim & $-1,55136^{*}$ & 0,21766 & 0,000 & $-2,1981$ & $-0,9047$ \\
\hline & Ulaştırma & $-1,12482^{*}$ & 0,18110 & 0,000 & $-1,6629$ & $-0,5867$ \\
\hline & Maliye & $-0,70633^{*}$ & 0,18365 & 0,003 & $-1,2520$ & $-0,1607$ \\
\hline & Üniversite & $-1,55546 *$ & 0,18365 & 0,000 & $-2,1011$ & $-1,0098$ \\
\hline & Diğer & $-0,96462$ & 0,21766 & 0,000 & $-1,6113$ & $-0,3179$ \\
\hline \multirow[t]{6}{*}{ Üniversite } & Sağlık & 0,51634 & 0,18763 & 0,090 & $-0,0412$ & 1,0738 \\
\hline & Eğitim & 0,00410 & 0,21133 & 1,000 & $-0,6238$ & 0,6320 \\
\hline & Ulaştırma & 0,43065 & 0,17345 & 0,170 & $-0,0847$ & 0,9460 \\
\hline & Maliye & 0,84913 & 0,17611 & 0,000 & 0,3259 & 1,3724 \\
\hline & Finans & $1,55546 *$ & 0,18365 & 0,000 & 1,0098 & 2,1011 \\
\hline & Diğer & 0,59085 & 0,21133 & 0,080 & $-0,0371$ & 1,2188 \\
\hline \multirow[t]{6}{*}{ Diğer } & Sağlık & $-0,07451$ & 0,22102 & 1,000 & $-0,7312$ & 0,5822 \\
\hline & Eğitim & $-0,58675$ & 0,24147 & 0,190 & $-1,3042$ & 0,1307 \\
\hline & Ulaştırma & $-0,16020$ & 0,20912 & 0,988 & $-0,7815$ & 0,4611 \\
\hline & Maliye & 0,25828 & 0,21133 & 0,885 & $-0,3696$ & 0,8862 \\
\hline & Finans & $0,96462 *$ & 0,21766 & 0,000 & 0,3179 & 1,6113 \\
\hline & Üniversite & $-0,59085$ & 0,21133 & 0,080 & $-1,2188$ & 0,0371 \\
\hline
\end{tabular}


Hüseyin GÜRBÜZ | Rüveyda DOĞAN | Elif GÖRMÜŞ | Gamze Pelin TOKYAY | Dilara ÖZTEKiN | Gökhan ENGiZ

Sektörlere göre yapılan işin özelliği ile ilgili farklılı̆ı incelendiğinde finans sektörünün diğer 6 sektöre göre anlamlı bir farklıı̆ının olduğu görülmektedir. Yapılan işin özelliğine göre Finans sektöründe diğer sektörlere göre daha az stres görülmekle beraber üniversite sektöründe ise maliye ve finans sektörüne göre daha fazla stres yaşanmaktadır.

\subsection{Yönetici ile ilgili Stres Kaynaklarının Sektörel Karşılaştırması}

Yönetici ile ilgili stres kaynaklarının sektörlere göre farklıığını ölçmek için tek yönlü varyans analizi testi uygulanmıştır.

Tablo 9. Varyans Analizi Tablosu

\begin{tabular}{lrrrrr}
\hline \hline Değişkenlik Kaynağı & Kareler Toplamı & S.d & Kareler Ortalaması & $F$ & $P$ \\
\hline Gruplar Arası & 37,696 & 6 & 6,283 & 9,434 & 0,0001 \\
Gruplar İçi & 175,818 & 264 & 0,666 & \\
Toplam & 213,514 & 270 & & & \\
\hline
\end{tabular}

$p<\alpha(0,0001<0,05)$ olduğundan dolayı sektörlere göre yönetime bakış açısı faktörü arasında anlamlı bir farklılık bulunmaktadır. Farklılığın hangi sektörden kaynaklandığının analizi (Tukey çoklu karşılaştırma sonuçları) Tablo 10'da verilmiştir.

Tablo 10. Tukey Çoklu Karşılaştırma Tablosu

\begin{tabular}{|c|c|c|c|c|c|c|}
\hline \multirow[b]{2}{*}{ Sektör } & \multirow[b]{2}{*}{ Sektör } & \multirow{2}{*}{$\begin{array}{r}\text { Ortalama } \\
\text { Fark }\end{array}$} & \multirow[b]{2}{*}{ S.d. } & \multirow[b]{2}{*}{$F$. } & \multicolumn{2}{|c|}{ \% 95 Güven Aralığı } \\
\hline & & & & & Alt Sınır & $\begin{array}{r}\text { Üst } \\
\text { Sınır }\end{array}$ \\
\hline \multirow[t]{6}{*}{$\begin{array}{l}\text { Sağlık } \\
\text { Eğitim }\end{array}$} & & $-0,41111$ & 0,21128 & 0,452 & $-1,0389$ & 0,2167 \\
\hline & Ulaştırma & $-0,35474$ & 0,17697 & 0,414 & $-0,8806$ & 0,1711 \\
\hline & Maliye & $0,65644^{*}$ & 0,17936 & 0,006 & 0,1235 & 1,1893 \\
\hline & Finans & 0,48299 & 0,18614 & 0,132 & $-0,0701$ & 1,0361 \\
\hline & Üniversite & 0,09551 & 0,17936 & 0,998 & $-0,4374$ & 0,6284 \\
\hline & Diğer & 0,15617 & 0,21128 & 0,990 & $-0,4716$ & 0,7839 \\
\hline \multirow{4}{*}{$\begin{array}{l}\text { Eğitim } \\
\text { Sağlık }\end{array}$} & & 0,41111 & 0,21128 & 0,452 & $-0,2167$ & 1,0389 \\
\hline & & 0,05636 & 0,19990 & 1,000 & $-0,5376$ & 0,6503 \\
\hline & Ulaştırma & $1,06754^{*}$ & 0,20201 & 0,000 & 0,4673 & 1,6678 \\
\hline & Maliye & $0,89409 *$ & 0,20806 & 0,000 & 0,2759 & 1,5123 \\
\hline
\end{tabular}


Eskişehir Osmangazi Üniversitesi Sosyal Bilimler Dergisi

$\begin{array}{rrrrrr}\text { Finans } & 0,50662 & 0,20201 & 0,161 & -0,0936 & 1,1068 \\ \text { Üniversite } & 0,56727 & 0,23082 & 0,179 & -0,1185 & 1,2531\end{array}$

Diğer

Ulaştırma Sağlık

Maliye

Sağlık

Finans

Sağlık

Üniversite

Sağlık

$\begin{array}{rrrrrr} & 0,35474 & 0,17697 & 0,414 & -0,1711 & 0,8806 \\ \text { Eğitim } & -0,05636 & 0,19990 & 1,000 & -0,6503 & 0,5376 \\ \text { Maliye } & 1,01118^{*} & 0,16580 & 0,000 & 0,5186 & 1,5038 \\ \text { Finans } & 0,83773^{*} & 0,17312 & 0,000 & 0,3234 & 1,3521 \\ \text { Üniversite } & 0,45025 & 0,16580 & 0,098 & -0,0424 & 0,9429 \\ \text { Diğer } & 0,51091 & 0,19990 & 0,144 & -0,0830 & 1,1048\end{array}$

$\begin{array}{rrrrrr} & -0,65644^{*} & 0,17936 & 0,006 & -1,1893 & -0,1235 \\ \text { Eğitim } & -1,06754^{*} & 0,20201 & 0,000 & -1,6678 & -0,4673 \\ \text { Ulaştırma } & -1,01118^{*} & 0,16580 & 0,000 & -1,5038 & -0,5186 \\ \text { Finans } & -0,17345 & 0,17555 & 0,956 & -0,6951 & 0,3482 \\ \text { Üniversite } & -0,56093^{*} & 0,16834 & 0,017 & -1,0611 & -0,0607 \\ \text { Diğer } & -0,50027 & 0,20201 & 0,172 & -1,1005 & 0,1000\end{array}$

$\begin{array}{rrrrrr} & -0,48299 & 0,18614 & 0,132 & -1,0361 & 0,0701 \\ \text { Eğitim } & -0,89409 * & 0,20806 & 0,000 & -1,5123 & -0,2759 \\ \text { Ulaştırma } & -0,8377 *^{*} & 0,17312 & 0,000 & -1,3521 & -0,3234 \\ \text { Maliye } & 0,17345 & 0,17555 & 0,956 & -0,3482 & 0,6951 \\ \text { Üniversite } & -0,38748 & 0,17555 & 0,295 & -1,9091 & 0,1341 \\ \text { Diğer } & -0,32682 & 0,20806 & 0,701 & -0,9450 & 0,2914\end{array}$

$\begin{array}{rrrrrr} & -0,09551 & 0,17936 & 0,998 & -0,6284 & 0,4374 \\ \text { Eğitim } & -0,50662 & 0,20201 & 0,161 & -1,1068 & 0,0936 \\ \text { Ulaştırma } & -0,45025 & 0,16580 & 0,098 & -0,9429 & 0,0424 \\ \text { Maliye } & 0,56093^{*} & 0,16834 & 0,017 & 0,0607 & 1,0611 \\ \text { Finans } & 0,38748 & 0,17555 & 0,295 & -0,1341 & 0,9091\end{array}$


Hüseyin GÜRBÜZ | Rüveyda DOĞAN | Elif GÖRMÜş | Gamze Pelin TOKYAY | Dilara ÖZTEKIN | Gökhan ENGiZ

\begin{tabular}{|c|c|c|c|c|c|c|}
\hline & Diğer & 0,06066 & 0,20201 & 1,000 & $-0,5396$ & 0,6609 \\
\hline \multirow[t]{6}{*}{$\begin{array}{l}\text { Diğer } \\
\text { Sağlık }\end{array}$} & & $-0,15617$ & 0,21128 & 0,990 & $-0,7839$ & 0,4716 \\
\hline & Fŏitim & $-0,56727$ & 0,23082 & 0,179 & $-1,2531$ & 0,1185 \\
\hline & Ulastırma & $-0,51091$ & 0,19990 & 0,144 & $-1,1048$ & 0,0830 \\
\hline & Maliye & 0,50027 & 0,20201 & 0,172 & $-0,1000$ & 1,1005 \\
\hline & Finans & 0,32682 & 0,20806 & 0,701 & $-0,2914$ & 0,9450 \\
\hline & Üniversite & $-0,06066$ & 0,20201 & 1,000 & $-0,6609$ & 0,5396 \\
\hline
\end{tabular}

Sektörlere göre yönetici ile ilgili stres kaynaklarının farklılığı incelendiğinde maliye sektörünün sağlık, eğitim, ulaştırma, üniversite sektörleriyle anlamlı bir farklıı̆ının olduğu görülmektedir. Aynı zamanda eğitim sektörünün de maliye ve finans sektörüyle anlamlı bir farklılı̆ı vardır. Maliye sektöründe çalışanlar sağılık, eğitim, ulaştırma, üniversite sektörlerine göre yönetim baskısı daha az, çalışan yönetici ilişkisi daha iyidir. Eğitim sektöründe çalışanlar ise maliye ve finans sektörüne göre daha çok yönetim baskısı hissetmektedirler.

\subsection{Maddi Olanaklar ile İlgili Stres Kaynaklarının Sektörel Karşılaştırma}

Tablo 11. Varyans Analizi Tablosu

\begin{tabular}{lrrrrr}
\hline \hline Değişkenlik Kaynağı & Kareler Toplamı & S.d & Kareler Ortalaması & $F$ & $P$ \\
\hline Gruplar Arası & 24,451 & 6 & 4,075 & 4,157 & 0,001 \\
Gruplar İçi & 258,798 & 264 & 0,980 & & \\
Toplam & 283,249 & 270 & & & \\
\hline
\end{tabular}

Maddi, olanaklar faktörünün sektörlere göre farklılı̆ı̆ı ölçmek için tek yönlü varyans analizi testi uygulanmıştır. $p<\alpha(0,001<0,05)$ olduğundan dolayı sektörlere göre maddi olanaklar faktörü açısından anlamlı bir farklıık bulunmaktadır. Bu farklıık ise; aşağıdaki tabloda incelenmiştir.

Tablo 12. Tukey Çoklu Karşılaştırma Tablosu

\begin{tabular}{llrrrrrr}
\hline \hline \multirow{2}{*}{ Sektör } & Sektör & Ortalama Fark & S.d. & F. & \multicolumn{2}{c}{ \% 95 Güven Aralığı } \\
& & & & & Alt Sınır & Üst Sınır \\
\hline \multirow{2}{*}{ Sağlık } & Eğitim & $-0,01605$ & 0,25633 & 1,000 & $-0,7777$ & 0,7456 \\
& Ulaştırma & $-0,60205$ & 0,21471 & 0,079 & $-1,2400$ & 0,0359 \\
\hline
\end{tabular}


Eskişehir Osmangazi Üniversitesi Sosyal Bilimler Dergisi

\begin{tabular}{|c|c|c|c|c|c|c|}
\hline & Maliye & $-0,19873$ & 0,21760 & 0,970 & $-0,8453$ & 0,4478 \\
\hline & Finans & 0,27095 & 0,22584 & 0,894 & $-0,4001$ & 0,9420 \\
\hline & Üniversite & $-0,22427$ & 0,21760 & 0,947 & $-0,8708$ & 0,4223 \\
\hline & Diğer & $-0,65405$ & 0,25633 & 0,146 & $-1,4157$ & 0,1076 \\
\hline \multirow[t]{6}{*}{ Eğitim } & Sağı̆ık & 0,01605 & 0,25633 & 1,000 & $-0,7456$ & 0,7777 \\
\hline & Ulaştırma & $-0,58600$ & 0,24252 & 0,196 & $-1,3066$ & 0,1346 \\
\hline & Maliye & $-0,18268$ & 0,24509 & 0,990 & $-0,9109$ & 0,5455 \\
\hline & Finans & 0,28700 & 0,25243 & 0,916 & $-0,4630$ & 1,0370 \\
\hline & Üniversite & $-0,20821$ & 0,24509 & 0,979 & $-0,9364$ & 0,5200 \\
\hline & Diğer & $-0,63800$ & 0,28004 & 0,259 & $-1,4701$ & 0,1941 \\
\hline \multirow[t]{6}{*}{ Ulaştırma } & Sağılık & 0,60205 & 0,21471 & 0,079 & $-0,0359$ & 1,2400 \\
\hline & Eğitim & 0,58600 & 0,24252 & 0,196 & $-0,1346$ & 1,3066 \\
\hline & Maliye & 0,40332 & 0,20115 & 0,414 & $-0,1944$ & 1,0010 \\
\hline & Finans & $0,87300 *$ & 0,21003 & 0,001 & 0,2489 & 1,4971 \\
\hline & Üniversite & 0,37779 & 0,20115 & 0,497 & $-0,2199$ & 0,9755 \\
\hline & Diğer & $-0,05200$ & 0,24252 & 1,000 & $-0,7726$ & 0,6686 \\
\hline \multirow[t]{6}{*}{ Maliye } & Sağlık & 0,19873 & 0,21760 & 0,970 & $-0,4478$ & 0,8453 \\
\hline & Eğitim & 0,18268 & 0,24509 & 0,990 & $-0,5455$ & 0,9109 \\
\hline & Ulaştırma & $-0,40332$ & 0,20115 & 0,414 & $-1,0010$ & 0,1944 \\
\hline & Finans & 0,46968 & 0,21299 & 0,296 & $-0,1632$ & 1,1025 \\
\hline & Üniversite & $-0,02553$ & 0,20424 & 1,000 & $-0,6324$ & 0,5813 \\
\hline & Diğer & $-0,45532$ & 0,24509 & 0,510 & $-1,1835$ & 0,2729 \\
\hline \multirow[t]{6}{*}{ Finans } & Sağlık & $-0,27095$ & 0,22584 & 0,894 & $-0,9420$ & 0,4001 \\
\hline & Eğitim & $-0,28700$ & 0,25243 & 0,916 & $-1,0370$ & 0,4630 \\
\hline & Ulaştırma & $-0,87300^{*}$ & 0,21003 & 0,001 & $-1,4971$ & $-0,2489$ \\
\hline & Maliye & $-0,46968$ & 0,21299 & 0,296 & $-1,1025$ & 0,1632 \\
\hline & Üniversite & $-0,49521$ & 0,21299 & 0,236 & $-1,1281$ & 0,1376 \\
\hline & Diğer & $-0,92500 *$ & 0,25243 & 0,005 & $-1,6750$ & $-0,1750$ \\
\hline
\end{tabular}


Hüseyin GÜRBÜZ | Rüveyda DOĞAN | Elif GÖRMÜş | Gamze Pelin TOKYAY | Dilara ÖZTEKIN | Gökhan ENGiZ

\begin{tabular}{llrrrrr}
\hline \hline Üniversite & Sağlık & 0,22427 & 0,21760 & 0,947 & $-0,4223$ & 0,8708 \\
& Eğitim & 0,20821 & 0,24509 & 0,979 & $-0,5200$ & 0,9364 \\
& Ulaştırma & $-0,37779$ & 0,20115 & 0,497 & $-0,9755$ & 0,2199 \\
& Maliye & 0,02553 & 0,20424 & 1,000 & $-0,5813$ & 0,6324 \\
& Finans & 0,49521 & 0,21299 & 0,236 & $-0,1376$ & 1,1281 \\
Diğer & Diğer & $-0,42979$ & 0,24509 & 0,581 & $-1,1580$ & 0,2984 \\
& Sağlık & 0,65405 & 0,25633 & 0,146 & $-0,1076$ & 1,4157 \\
& Eğitim & 0,63800 & 0,28004 & 0,259 & $-0,1941$ & 1,4701 \\
& Ulaştırma & 0,05200 & 0,24252 & 1,000 & $-0,6686$ & 0,7726 \\
& Maliye & 0,45532 & 0,24509 & 0,510 & $-0,2729$ & 1,1835 \\
& Finans & $0,95200 *$ & 0,25243 & 0,005 & 0,1750 & 1,6750 \\
& Üniversite & 0,42979 & 0,24509 & 0,581 & $-0,2984$ & 1,1580 \\
\hline
\end{tabular}

Sektörlere göre maddi olanaklar faktörünün farklılığı incelendiğinde finans sektörünün ulaştırma ve diğer sektörlerle anlamlı bir farklıı̆̆ının olduğu görülmektedir. Finans sektörü ulaştırma ve diğer sektörlere göre maddi olanaklar yönünden daha rahattır.

5.8. Mesleki İlerleme, Terfi ve Takdir ile İgili Stres Kaynaklarının Sektörel Karşılaştırması

Tablo 13. Varyans Analizi Tablosu

\begin{tabular}{lrrrrr}
\hline \hline Değişkenlik Kaynağı & Kareler Toplamı & S.d & Kareler Ortalaması & $F$ & $P$ \\
\hline Gruplar Arası & 34,576 & 6 & 5,763 & 5,990 & 0,0001 \\
Gruplar İçi & 253,969 & 264 & 0,962 & & \\
Toplam & 288,545 & 270 & & & \\
\hline
\end{tabular}

Mesleki ilerleme, terfi ve takdir ile ilgili stres kaynaklarının sektörlere göre farklılı̆ını ölçmek için yapılan tek yönlü varyans analizi testinin sonucunda $p<\alpha(0,0001<0,05)$ olduğundan, sektörlere göre, mesleki ilerleme, terfi ve takdir ile ilgili stres kaynakları açısından anlamlı bir farklılık bulunmaktadır. Bu farkıı̆ı̆ın hangi sektörden kaynaklandığını belirlemek için Tukey Çoklu Karşılaştırma analizi yapılmıştır. 
Eskişehir Osmangazi Üniversitesi Sosyal Bilimler Dergisi

Tablo 14. Tukey Çoklu Karşılaştırma Tablosu

\begin{tabular}{|c|c|c|c|c|c|c|}
\hline \multirow{2}{*}{ Sektör } & \multirow{2}{*}{ Sektör } & \multirow{2}{*}{$\begin{array}{r}\text { Ortalama } \\
\text { Fark }\end{array}$} & \multirow{2}{*}{ S.d. } & \multirow{2}{*}{$F$. } & \multicolumn{2}{|c|}{ \% 95 Güven Aralığı } \\
\hline & & & & & Alt Sinır & Üst Sınır \\
\hline \multirow[t]{6}{*}{ Sağlık } & Eğitim & $-0,62991$ & 0,25393 & 0,171 & $-1,3844$ & 0,1246 \\
\hline & Ulaştırma & $-0,10991$ & 0,21270 & 0,999 & $-0,7419$ & 0,5221 \\
\hline & Maliye & $0,70002 *$ & 0,21556 & 0,022 & 0,0595 & 1,3405 \\
\hline & Finans & 0,06569 & 0,22372 & 1,000 & $-0,5996$ & 0,7298 \\
\hline & Üniversite & 0,23193 & 0,21556 & 0,935 & $-0,4086$ & 0,8724 \\
\hline & Diğer & $-0,09658$ & 0,25393 & 1,000 & $-0,8511$ & 0,6579 \\
\hline \multirow[t]{6}{*}{ Eğitim } & Sağlık & 0,62991 & 0,25393 & 0,171 & $-0,1246$ & 1,3844 \\
\hline & Ulaştırma & 0,52000 & 0,24025 & 0,319 & $-0,1938$ & 1,2338 \\
\hline & Maliye & $1,32993 *$ & 0,24279 & 0,000 & $-0,6085$ & 2,0513 \\
\hline & Finans & 0,69500 & 0,25006 & 0,084 & $-0,0480$ & 1,4380 \\
\hline & Üniversite & $0,86184 *$ & 0,24279 & 0,008 & 0,1405 & 1,5832 \\
\hline & Diğer & 0,53333 & 0,27742 & 0,467 & $-0,2909$ & 1,3576 \\
\hline \multirow[t]{6}{*}{ Ulaştırma } & Sağlık & 0,10991 & 0,21270 & 0,999 & $-0,5221$ & 0,7419 \\
\hline & Eğitim & $-0,52000$ & 0,24025 & 0,319 & $-1,2338$ & 0,1938 \\
\hline & Maliye & $0,80993 *$ & 0,19927 & 0,001 & 0,2179 & 1,4020 \\
\hline & Finans & 0,17500 & 0,20806 & 0,980 & $-0,4432$ & 0,7932 \\
\hline & Üniversite & 0,34184 & 0,19927 & 0,606 & $-0,2502$ & 0,9339 \\
\hline & Diğer & 0,01333 & 0,24025 & 1,000 & $-0,7005$ & 0,7272 \\
\hline \multirow[t]{6}{*}{ Maliye } & Sağlık & $-0,70002 *$ & 0,21556 & 0,022 & $-1,3405$ & $-0,0595$ \\
\hline & Eğitim & $-1,32993 *$ & 0,24279 & 0,000 & $-2,0513$ & $-0,6085$ \\
\hline & Ulaştırma & $-0,80993^{*}$ & 0,19927 & 0,001 & $-1,4020$ & $-0,2179$ \\
\hline & Finans & $-0,63493^{*}$ & 0,21099 & 0,045 & $-1,2618$ & $-0,0080$ \\
\hline & Üniversite & $-0,46809$ & 0,20233 & 0,241 & $-1,0692$ & 0,1331 \\
\hline & Diğer & $-0,79660 *$ & 0,24279 & 0,020 & $-1,5180$ & $-0,0752$ \\
\hline Finans & Sağlık & $-0,06509$ & 0,22372 & 1,000 & $-0,7298$ & 0,5996 \\
\hline
\end{tabular}


Hüseyin GÜRBÜZ | Rüveyda DOĞAN | Elif GÖRMÜŞ | Gamze Pelin TOKYAY | Dilara ÖZTEKiN | Gökhan ENGiZ

\begin{tabular}{|c|c|c|c|c|c|c|}
\hline & Eğitim & $-0,69500$ & 0,25006 & 0,084 & $-1,4380$ & 0,0480 \\
\hline & Ulaştırma & $-0,17500$ & 0,20806 & 0,980 & $-0,7932$ & 0,4432 \\
\hline & Maliye & $-0,63493^{*}$ & 0,21099 & 0,045 & 0,0080 & 1,2618 \\
\hline & Üniversite & 0,16684 & 0,21099 & 0,986 & $-0,4601$ & 0,7938 \\
\hline & Diğer & $-0,16167$ & 0,25006 & 0,995 & $-0,9047$ & 0,5813 \\
\hline \multirow[t]{6}{*}{ Üniversite } & Sağlık & $-0,23193$ & 0,21556 & 0,935 & $-0,8724$ & 0,4086 \\
\hline & Eğitim & $-0,861184 *$ & 0,24279 & 0,008 & $-1,5832$ & $-0,1405$ \\
\hline & Ulaştırma & $-0,34184$ & 0,19927 & 0,606 & $-0,9339$ & 0,2502 \\
\hline & Maliye & 0,46809 & 0,20233 & 0,241 & $-0,1331$ & 1,0692 \\
\hline & Finans & $-0,16684$ & 0,21099 & 0,986 & $-0,7938$ & 0,4601 \\
\hline & Diğer & $-0,32851$ & 0,24279 & 0,826 & $-1,0499$ & 0,3929 \\
\hline \multirow[t]{6}{*}{ Diğer } & Sağlık & 0,09658 & 0,25933 & 1,000 & $-0,6579$ & 0,8511 \\
\hline & Eğitim & $-0,53333$ & 0,27742 & 0,467 & $-1,3576$ & 0,2909 \\
\hline & Ulaştırma & $-0,01333$ & 0,24025 & 1,000 & $-0,7272$ & 0,7005 \\
\hline & Maliye & $0,79660 *$ & 0,24279 & 0,020 & 0,0752 & 1,5180 \\
\hline & Finans & 0,16167 & 0,25006 & 0,995 & $-0,5813$ & 0,9047 \\
\hline & Üniversite & 0,32851 & 0,24279 & 0,826 & $-0,3929$ & 1,0499 \\
\hline
\end{tabular}

Sektörlere göre mesleki ilerleme, terfi ve takdir ile ilgili stres kaynaklarının farklılığı incelendiğinde maliye sektörünün sağlık, eğitim, ulaştırma, finans ve diğer sektörlerle anlamlı bir farklılığının olduğu görülmektedir. Aynı zamanda eğitim sektörünün de maliye ve üniversite sektörüyle anlamlı bir farklılığı vardır. Maliye sektöründeki iş görenler eğitim ve ulaştırma sektöründeki iş görenlere göre daha az mesleki terfi ve takdir imkanına ulaşmakta, eğitim sektöründeki iş görenler ise maliye ve üniversite sektöründeki iş görenlere göre daha fazla mesleki terfi ve takdir imkanına ulaşmaktadırlar.

\section{Sonuç}

Stres oluşumunda birçok çevresel faktör rol oynamakta ve bu çevresel faktörler stres yaratıcı ortam oluşturmaktadır. Günümüzde çalışanlar ve yöneticiler çok rekabetli, değişken, belirsizlik ve hatta muğlaklığın hakim olduğu iş ortamlarında çalışmaktadırlar. Özellikle stres yaratan faktörler, yönetici ve çalışanların kontrol altına alamayacakları nitelikte, diğer bir değişle, yakın ve genel çevre koşullarından kaynaklanmakta ise, yönetici ve çalışanlar bu ortamlara özveri ve uyum göstermekte 
zorlanmaktadırlar. Bu durum, örgütte, örgütsel stres kavramının ortaya çıkmasına neden olmuş, bilim adamları ve araştırmacıları bu konuda çalışmaya, araştırma yapmaya, fikirler ve yeni düşünceler üretmeye yöneltmiştir.

Bu çalışmada; finans, maliye, eğitim, üniversite, sağlık, ulaştırma personeli üzerinde bir araştırma yapılmıştır. Araştırmada, bu sektördeki kamu personelini etkileyen örgütsel stres kaynaklarını, personelin iş performansını olumsuz yönde etkileyen ve amaçlarına ulaşmada kendilerini rahatsız eden stres kaynakları belirlenmeye çalışılmış, stresin bu kişiler üzerinde ne derece etki ettiği açığa çıkarılmıştır. Yapılan anket çalışmasında, stres, yönetime bakış açısı, maddi olanaklar ve iş tatmini faktörleri durumları yer almıştır.

Özellikle yapılan analizden de anlaşılacağı üzere, sektörlerin stres ve iş tatmini üzerine çalışanlarına hizmet içi eğitimler vermesi gerekmektedir. Ayrıca yöneticilerin çalışanlarına açık net anlaşıır şekilde talimat vermeleri, çalışanlara görev alanı dışındaki işler verildiğinde baskı oluşturmamaları gerekmektedir. Kamu alanında çok yaygın görülmeyen ödüllendirme sisteminin oluşması ise iş görenlerin performansını artıran bir faktör olduğu unutulmamalı, bu yönde çalışmalar yapılmalıdır.

Stresle etkili bir biçimde başa çıkılması gerekir. Stresle başa çıkmada herkes için iyi olan ortak bir çözüm yolu yoktur. Her insanın zayıf noktası, devamlı olarak strese maruz kaldığı zaman açık veren zayıf bir yönü vardır. Bundan dolayı, kişi kendi kişilik ve yaşam tarzına uygun olan yöntemleri bulup denemelidir. Bir başka deyişle birey stresinin yönetimini ele almalıdır.

\section{Kaynaklar}

Akar C. , Yıldırım T. (2008). "Yöneticilerin Örgütsel Bağlııı, İş Tatmini Ve Rol Stres Kaynakları Arasındaki Ilişkiler: Yapısal Denklem Modeliyle Beyaz Et Sektöründe Bir Alan Uygulaması" Gazi Üniversitesi Iktisadi Ve İdari Bilimler Fakültesi Dergi, i c:10, S:2.

Akgündüz, S. (2006). “Örgütsel Stres Kaynaklarının Çalışanların İş Tatmini Üzerindeki Etkisi ve Banka Çalışanları İçin Yapılan Bir Araştırma”, Yüksek Lisans Tezi.

Arı G., Bal H. , Bal E. (2010). "Işe Bağlılığın Tükenmişlik Ve İşten Ayrılma Niyeti ilişkisindeki Aracılık Etkisi: Yatırım Uzmanları Üzerinde Bir Araştırma”, Süleyman Demirel Üniversitesi İktisadi Ve İdari Bilimler Fakültesi Dergisi, C.15, S.3.

Atılgan T. , Dengizler i. (2007). "Hazır Giyim Sektöründe Örgütsel Stres Üzerine Bir Araştırma” Dokuz Eylül Üniversitesi Sosyal Bilimler Enstitüsü Dergisi, C: 9, S: 2.

Aydın Ş. (2004). “Örgütsel Stres Yönetimi”, Dokuz Eylül Üniversitesi Sosyal Bilimler Dergisi C. 6, S: 3.

Baltaş, A. ve Batlaş Z. (1999). Stres ve Başa Çıkma Yolları, Remzi Kitabevi.

Batıgün A. , ŞAHiN N. (2006). “iş Stresi ve Sağlık Psikolojisi Araştırmaları İçin İki Ölçek: A-Tipi Kişilik ve İş Doyumu”, Türk Psikiyatri Dergisi, , 17(1):32-45. 
Hüseyin GÜRBÜZ | Rüveyda DOĞAN | Elif GÖRMÜŞ | Gamze Pelin TOKYAY | Dilara ÖZTEKiN | Gökhan ENGiZ

Başaran, i. Ethem. (1982). Örgütsel Davranış, A.Ü. Eğitim Bilimleri Fakültesi Yayını, Ankara.

Braham, B. J. (1998). Stres Yönetimi. Ateş Altında Sakin Kalabilmek, (Çev.: Vedat G. Diker), Hayat Yayınları, İstanbul.

Cüceloğlu, D. (1994). Insan ve Davranışı, Psikolojinin Temel Kavramları, Remzi Kitabevi, İstanbul.

Erdoğan, i. (1999). İ̧̧letme Yönetiminde Örgütsel Davranış, Dönence Basım ve Yayın Hizmetleri, İstanbul.

Ersarı, G., Naktiyok, A. (2012). “iş Görenin İçsel ve Dışsal Motivasyonunda Stresle Mücadele Tekniklerinin Rolü” Atatürk Üniversitesi Sosyal Bilimler Enstitüsü Dergisi 201216 (1): s. 81101,Erzurum.

Emhan, A. , Gök R. (2011). "Bankacılık Sektöründe Personel Memnuniyeti ve Örgütsel Bağlılık Arasındaki ilişkilerin Araştırılması.” Finansman ve Muhasebe Dergisi (Temmuz 2011).

Ertekin, Y. (1993). Stres ve Yönetim, TODAiE, Ankara.

Eren, E., (2004). Örgütsel Davranış ve Yönetim Psikolojisi, Beta Basım Yayım Dağıım, İstanbul.

Garipoğlu, E., (2007). "Stres Yönetimi ve Banka Çalışanları Üzerine Yapılan Bir Araştırma" Yüksek Lisans Tezi

Gümüştekin G. (Temmuz-Aralık 2004). "Örgütsel Stres Yönetimi Ve Uçucu Personel Üzerinde Bir Uygulama”, Erciyes Üniversitesi Iktisadi Ve İdari Bilimler Fakültesi Dergisi,), S: 23, Ss. 61-85.

Güney, S. (2007). Yönetim ve Organizasyon, Nobel Yayın Dağıtım, Ankara.

Kök S. (Nisan 2006). "İş Tatmini Ve Örgütsel Bağlılığın İncelenmesine Yönelik Bir Araştırma”, Pamukkale Üniversitesi İktisadi ve İdari Bilimler Dergisi, C: 20 S: 1.

Lewis, D., (1995). Bir Dakikada Stres Yönetimi, Çev. Nedime Harmandaglı, Arda's Yayınları, İzmir.

Pehlivan, i̇. (1995). Yönetimde Stres Kaynakları, Pegem Yayınları, Ankara.

Poyraz K. , Kama B. (2008). “Algılanan İş Güvencesinin, İş Tatmini Örgütsel Bağlılık ve İşten Ayrılma Niyeti Üzerindeki Etkilerinin İncelenmesi", Süleyman Demirel Üniversitesi İktisadi ve İdari Bilimler Fakültesi Dergisi C.13, S.2.

Şahin, N., (1995). Stresle Başa Çıkma. Olumlu Bir Yaklaşım, Sistem Yayıncılık, İstanbul.

Şimşek, M. Şerif, Tahir Akgemci, Adnan Çelik (2001). Davranış Bilimlerine Giriş ve Örgütlerde Davranış, (2. Baskı), Nobel Yayın Dağıım, Ankara.

Uzun Ö. , Yiğit E. (Nisan 2011). “Örgütsel Stres Ve Örgütsel Bağllık İlişkisi Üzerine Orta Kademe Otel Yöneticileri Üzerinde Yapılan Bir Araştırma”, ESOGÜ iïBF Dergisi, 6(1), 181-213. 